\title{
Individual Learner Differences and Second Language Acquisition: A Review
}

\author{
Shahila Zafar \\ School of Social Sciences and Languages, VIT University, Vellore-632014, TN, India \\ Email: shahela.zafar@gmail.com \\ K. Meenakshi \\ School of Social Sciences and Languages, VIT University, Vellore-632014, TN, India \\ Email: k.meenakshi@vit.ac.in
}

\begin{abstract}
The level of second language acquisition depends on many factors controlled by nature or shaped by nurture. The present paper studies the role of individual learner differences in second language acquisition (SLA). The individual differences, viz., age, sex, aptitude, motivation, cognitive style, learning strategies, and personality are defined and classified. A detailed review of the studies conducted in relation to the seven individual differences follows. The paper concludes by emphasizing that a language teacher must recognize the individual differences in his/ her students in order to impart effective language learning.
\end{abstract}

Index Terms - second language acquisition, individual learner difference, personality, age, sex, aptitude, motivation, cognitive style, learning strategies

\section{INTRODUCTION}

Why do some people almost achieve the native speaker's levels of competence in a foreign language while others never seem to progress much beyond a beginner's level? Some second language learners make rapid and apparently effortless progress while others progress only very slowly and with great difficulty. The reason probably is that people are not homogenous! They have different personalities and styles. Thus, each individual is different from the other. These individual differences, according to Dörnyei, (2005) are, "enduring personal characteristics that are assumed to apply to everybody and on which people differ by degree."

Humans differ from each other due to many biological or conditioned factors (affected by nature) or unconscious forces (affected by past experiences). The many ways in which one learns about these differences are usually similar, through introspection and interaction with other people, or by reading books and watching television or cinema. However, in order to conduct research in individual differences, it is necessary to have rigorous instruments, and a scientific way of providing reliable and valid. The differences that one can explore are:
A. Age
B. Sex
C. Aptitude
D. Motivation
E. Learning Styles
F. Learning Strategies
G. Personality

The above mentioned differences are intricately interlocked with each other and in totality play important roles in language learning. Language teachers should be aware of their effects. In compared to the linguistics factors, these nonlinguistic factors are not given much importance in SLA research. Still many researchers over the years have made significant efforts at exploring the role of these factors. In a sequence, we will take a look at their role in second language learning.

\section{INDIVIDUAL DIFFERENCES AND SLA}

\section{A. Age}

Are children more successful second language learners than adults? Many would say yes, if we commonly observe the ease with which children, especially young children slip into the role of second language speakers. But Saville-Troike (2006) warns us against such easy assumptions and argues that that one must define the term 'success' (89). According to her, "Some define "success" as initial rate of learning while other studies define it as ultimate achievement. Also, some studies define "success" in terms of how close the learner's pronunciation is to a native speaker's, others in terms of how closely a learner approximates native grammaticality judgments and still others in 
terms of fluency or functional competence (89)". She further warns that the evaluative criteria clearly must be kept clearly in mind while judging conflicting claims about success.

It is believed that there is a critical period for first language acquisition. Children are believed to have only a limited number of years during which normal acquisition is possible. Beyond that, physiological changes cause the brain to lose its plasticity, or capacity to assume the new functions that learning language demands. Individuals who for some reason are deprived of the linguistic input which is needed to trigger first language acquisition during the critical period will never learn any language normally. One famous case that provides rare evidence for this point is that of Genie, an abused girl who was kept isolated from all language input and interaction until she was thirteen years old. In spite of years of intensive efforts at remediation, Genie never developed linguistic knowledge and skills for her L1 (English) that were comparable to those of speakers who began acquisition in early childhood.

For a long time, a debate on the existence or absence of a critical period of language learning has been going on in the field of SLA. A critical period means that beyond a particular age successful acquisition of a second language is not possible due to physiological changes in the brain (Kim et al., 1997). Moreover, as one gets older, one becomes more self-conscious which hinders him/her from making full use of his/her language skills, especially speaking skills.

A more sophisticated version of the critical period hypothesis is the concept of 'sensitive' period for language learning by Slobin (1982). The sensitive period implies that there is a period in one's life (during childhood) when second language acquisition is optimized. Slobin (1982) argues that of the sensitive period of language learning is proven by the fact that the universal age of onset of production, rate of acquisition and age of completion of language learning is the same and it is relatively unaffected by the environmental variations and individual cognitive ability. It is hypnotized that once this critical/ sensitive period is over, a child deprived of input and chances to communicate is never able to regain his/her ability to acquire language as happened in the case of 'Genie' who after her release from solitary captivation since early childhood was not able to learn even the basic language skills after she was rescued at the age of thirteen.

So how much difference does age make? Long (1990) argues that for language learners of more than 15 years of age, it is difficult to acquire native like fluency and an absence of an 'accent'. Saville-Troike (2006) agrees with Long (1990) that, "some older learners can achieve native-like proficiency, although they definitely constitute a minority of second language learners (89)."

The critical/ sensitive period hypothesis is yet to be tested at the scientific level and SLA theorists have a long way to before the find a clear and final answer to the fascinating question of why and how children seem to be better (second) language learners.

\section{B. Sex}

Many studies (e.g., Oxford, 1993; Young \& Oxford 1997) have found that gender can have a significant impact on how students learn a language. Although the study of gender as a variable in language learning is still at an early stage (Bacon \& Finneman, 1992; Oxford, 1993; Ehrman \& Oxford, 1995), studies of individual language learner differences related to sex (biological) or gender (socially constructed) have shown that females tend to show greater integrative motivation and more positive attitudes to L2, and use a wider range of learning strategies, particularly social strategies (Oxford, Nyikos \& Ehrman, 1988). As a matter of fact, as for the problem whether difference exists between male and female in terms of learning a language, Larsen-Freeman \& Long (2000) believed that in the process of first language acquisition female excel male, at least at the early stage. Zhuanglin (1989) highlighted that, it was generally believed that male and female are born with different linguistic advantages, such as, female learn to speak earlier than male, and female learn a foreign language faster and better than male, etc.

Studies of actual results suggest females are typically superior to males in nearly all aspects of language learning, except listening vocabulary (Boyle, 1987). Kimura (1992, as cited in Saville-Troike, 2006)), reports that higher levels of articulatory and motor ability have been associated in women with higher levels of estrogen level during the menstrual cycle.

\section{Aptitude}

Skehan, (1989) believes that aptitude has consistently been linked with L2 success, but remains one of the under investigated areas of SLA. Saville-Troike (2006) suggests that assumption that there is a talent which is specific to language learning has been widely held for many years. Many language aptitude tests like TOEFL, IELTS have been used for a long period to test the aptitude of a second language learner of English. Carroll (1963), who along with Sapon created the Modern Language Aptitude Test (MLAT) which was designed to predict success foreign language learning, provides us with the following four types of abilities that constitute aptitude:

i. Phonemic coding ability (discriminates and encodes foreign sounds)

ii. Grammatical sensitivity (recognizes functions of words in sentences)

iii. Inductive language learning ability (infers or induces rules from samples)

iv. Memory and learning (makes and recalls associations between words and phrases in L1 and L2)

Many scholars believe that aptitude alone does not determine the language learning ability of an individual. Skehan (1989) suggests that individual ability may vary by other factors. Other factors like personality, language learning style and motivation must be considered before taking into account. Skehan (1989) further concludes that language-learning 
aptitude "is not completely distinct from general cognitive abilities, as represented by intelligence tests, but it is far from the same thing". Moreover, aptitude can only predict success in second language acquisition; it cannot explain the reasons behind it.

\section{Motivation}

Motivation to learn a language is considered one of the most plausible reasons of success at second language acquisition. According to Gardner (1985) Motivation = effort + desire to achieve goal + attitudes. Saville-Troike (2006) claims that motivation is the second strongest predictor (after aptitude) of second language success. She further argues that motivation largely determines the level of effort that learners expend at various stages in their L2 development, often a key to ultimate level of proficiency.

According to Gardner and Lambert (1972) the following two types of motivation exist:

i. Integrative: found in individuals who want are interested in the second language in order to integrate with and become a part of a target community/ culture; here the learner wants to resemble and behave like the target community.

ii. Instrumental: found in individuals who want to get learn a second language with the objective of getting benefits from the second language skill. Objectives, such as business advancement, increase in professional status, educational goals etc. motivate an individual to learn a second language in this case.

Both the types of motivations have different roles to play. Both can lead to success. According to Saville-Troike (2006) the relative effect of one or the other is dependent on complex personal and social factors. L2 learning by a member of the dominant group in a society may benefit more from integrative motivation, and L2 learning by a subordinate group member may be more influenced by instrumental motivation.

In most of the motivation research, the relationship between motivation and second language achievement has been shown as a strong one. But whether the achievement drives motivation or motivation drives achievement is yet to be tested.

\section{E. Learning Styles}

Language learning styles refer to cognitive variations in learning a second language. It is about an individuals' preferred way of processing, that is, of perceiving, conceptualizing, organizing, and recalling information related to language learning. According to Cornett (1983) the language learning styles are the overall patterns that give general direction to learning behavior. Brown (2000) states that unlike factors of age, aptitude, and motivation, its role in explaining why some L2 learners are more successful than others has not been well established, it involves a complex (and as yet poorly understood) interaction with specific L2 social and learning contexts.

The following cognitive styles have been identified by Knowles (1972 as cited in Lochart \& Richards, 1994):

1. Concrete learning style

Learners with a concrete learning style use active and direct means of taking in and processing information. They are interested in information that has immediate value. They are curious, spontaneous, and willing to take risks. They like variety and a constant change of pace. They dislike routine learning and written work, and prefer verbal or visual experiences. They like to be entertained, and like to be physically involved in learning.

\section{Analytical learning style}

Learners with an analytical style are independent, like to solve problems, and enjoy tracking down ideas and developing principles on their own. Such learners prefer a logical, systematic presentation of new learning material with opportunities for learners to follow up on their own. Analytical learners are serious, push themselves hard, and are vulnerable to failure.

\section{Communicative learning style}

Learners with a communicative learning style prefer a social approach to learning. They need personal feedback and interaction, and learn well from discussion and group activities. They thrive in a democratically run class.

\section{Authority-oriented learning style}

Learners with an authority-oriented style are said to be responsible and dependable. They like and need structure and sequential progression. They relate well to a traditional classroom. They prefer the teacher as an authority figure. They like to have clear instructions and to know exactly what they are doing; they are not comfortable with consensus-building discussion.

Another set of language learning style according to Witkin (1973), is the cognitive learning styles. These styles are of two types:

1. Field Independent (left brain dominance)

2. Field Dependent style ( right brain dominance)

A learner with a field independent style is usually an independent and confident being who see parts and details from a whole. The rational, logical and mathematical side of his/her mind is more active during the process of learning. Such a learner thrives in a class full of activities and exercises. On the other hand, a field dependent learner is better at grasping the observing ideas and observing the whole situation. He is visually and emotionally oriented. For such a person communication and interaction help in second language acquisition as he is usually a social being.

It is important for a learner to be aware of one's learning style but Oxford (2003) warns us against being too rigid 
about the types as they "are not dichotomous (black or white, present or absent). Learning styles generally operate on a continuum or on multiple, intersecting continua (p.3)."

\section{F. Learning Strategies}

The learning strategies are the strategies a learner selects for language acquisition. Brown (2000) argues that the choice of learning strategies is strongly influenced by the nature of their motivation, cognitive style, and personality, as well as by specific contexts of use and opportunities for learning.

Many studies in SLA have ventured out to identify which strategies are used by relatively good language learners, with the expectation that such strategies can be taught or otherwise applied to enhance learning. According to O’Malley and Chamot (1990) strategies are the tools for active, self-directed involvement needed for developing L2 communicative ability. O’Malley and Chamot, (1990) have identified the following strategies:

1. Cognitive strategies

Cognitive strategies "operate directly on incoming information, manipulating it in ways that enhance learning". Some of these strategies are

- Repetition: imitating other people's speech overtly or silently;

- Resourcing: making use of language materials such as dictionaries;

- Directed Physical Response: responding physically "as with directives";

- Translation: using the first language as a basis for understanding and/or producing the L2;

- Grouping: organizing learning on the basis of "common attributes";

- Note-taking: writing down the gist etc of texts;

- Deduction: conscious application of rules to processing the L2;

- Recombination: putting together smaller meaningful elements into new wholes;

- Imagery: visualizing information for memory storage;

- Auditory Representation: keeping a sound or sound sequence in the mind;

- Key Word: using key word memory techniques, such as identifying an L2 word with an L1 word that it sounds like;

- Contextualization: placing a word or phrase in a meaningful language sequence;

- Elaboration: relating new information to other concepts in memory;

- Transfer: using previous knowledge to help language learning;

- Inferencing: guessing meanings by using available information;

- Question for Clarification: asking a teacher or native speaker for explanation, help, etc..

2. Metacognitive strategies

Metacognitive strategies are skills used for planning, monitoring, and evaluating the learning activity; "they are strategies about learning rather than learning strategies themselves". The following are some of the metacognitive strategies

- Advance Organizers: planning the learning activity in advance;

- Directed Attention: deciding to concentrate on general aspects of a learning task;

- Selective Attention: deciding to pay attention to specific parts of the language input or the situation that will help learning;

- Self-management: trying to arrange the appropriate conditions for learning;

- Advance Preparation: planning the linguistic components for a forthcoming language task;

- Self-monitoring: checking one's performance as one speaks;

- Delayed Production: deliberately postponing speaking so that one may learn by listening;

- Self-evaluation: checking how well one is doing against one's own standards;

- Self- reinforcement: giving oneself rewards for success.

3. Social and affective strategies

Social and affective strategies involve interacting with another person to assist learning or using control to assist a learning task. These strategies are:

- Questioning for Clarification: Asking for explanation, verification, rephrasing, or examples about the material; asking for clarification or verification about the task; posing questions to the self.

- Cooperation: Working together with peers to solve a problem, pool information, check a learning task, model a language activity, or get feedback on oral or written performance.

- Self-talk: Reducing anxiety by using mental techniques that make one feel competent to do the learning task.

Distinction between styles and strategies

According to Lombaard (2006) Language learning styles characterize the consistent and rather enduring traits, tendencies, or preferences that may differentiate you from another person while strategies are specific methods of approaching a problem or task, modes of operation for achieving a particular end, or plan designed for controlling and manipulating certain information. Strategies vary widely within an individual, while styles are more constant and predictable (20).

Oxford (2003) argues for need for awareness amongst teachers regarding the types of strategies used by students in a class as she believes that it foolhardy to think that a single L2 methodology could possibly fit an entire class filled with students who have a range of stylistic and strategic preferences. 


\section{G. Personality}

Human personality in all its shapes and colors brings variety to this world. Personality studies have been the core of the study of human psychology for more than 150 years. Eminent psychologists like Freud, Skinner and Allport focused their studies on human personality. In SLA the study of the relation of personality and language learning has been the subject of scholars like Krashen (1985), Skehan (1989), Gass \& Selinker, (1994) etc. one tends to agree with Ehrman (1996) when he suggests that there is a clear relationship between personality and SLA as personality determines what people feel comfortable with. As a result, people tend to choose and consequently do what they feel comfortable with and get better at the given skills (p.101). Thus, a second language learner will make choices of strategies and skills according to bent of his/her personality.

There are a number of personality characteristics that may affect L2 learning, such as:

1. Extroversion vs. introversion

2. Self esteem

3. Inhibition

4. Risk-taking

5. Anxiety

Each of the above aspects is discussed in the following sections:

1. Extroversion vs. Introversion

According to Dawaele and Furnham (1999) eextroversion and introversion are a part of a continuum. Extroverts are considered sociable and impulsive. They seem to dislike solitude, take risks, impulsive. Whereas, introverts are believed to be introspective, quiet, retiring and reserved. An extrovert is said to receive energy from outside sources, whereas an introvert is more concerned with the inner world of ideas and is more likely to be involved with solitary activities. This trait does not just describe whether a person is outgoing or shy, but considers whether a person prefers working alone or feels energized and at home working in a team.

The relationship between extroversion and learning was first studied by Eysenck who hypothysed that extroversion was not positively correlated with learning due to several neuro-chemical phenomena in the human brain. Thus he concluded that an introvert and not an extrovert would be a better language learner.

The SLA theorists, however, tend to disagree with Eysenck's conclusion. It is often argued that an extroverted person is well suited to language learning. SLA literature suggests that the more extravert language learners would increase the amount of input (Krashen, 1985), prefer communicative approaches (Cook, 2001), the more they are likely to join the group activities (McDonough, 1986). Therefore, they increase their interaction in the language which maximizes the language output (Swain, 1985), hence yield a better product i.e. language proficiency. However, research does not always support this conclusion. Some studies have found that learners' success in language learning is associated with extroversion such as assertiveness and adventurousness, while others have found that many successful language learners do not get high scores on measures of extroversion.

2. Self esteem

Many researchers claim that no successful learning activity can take place without some self- esteem and self confidence. Coopersmith (1967) defines self- esteem as a personal judgment of worthiness that is expressed in the attitudes that the individual holds towards himself/herself. Brodkey and Shore (1976) revealed that self-esteem appears to be an important variable in SLA, particularly in view of cross-cultural factors of second language learning.

Brodkey and Shore (1976), and Gardner and Lambert (1972) studied self esteem and concluded that it was an important factor in second language acquisition. Heyde's Self-Esteem Study (1979) also concluded that self esteem generated by high involvement of teachers let to better results in second language acquisition. MacIntyre, Dörnyei, Clement, \& Noels (1998) studies the role of self confidences in their model of "willingness to communicate" in a foreign language. Their results showed that a better ability to communicate did lead to more willingness to communicate. A number of factors appear to contribute to predisposing one learner to seek, and another learner to avoid, second language communication. They suggested that not one but many factors that lead to willingness to communicate. Of these, motivation, personality, intergroup climate, and two levels of self-confidence are a few. Of the two levels of self-confidence the first level resembles "state communicative self-confidence"; the second, an general level "L2 self-confidence". Both self-confidence factors assume important roles in determining one's willingness to communicate. But as has been the case with many other individual factors, it is believed that high self-esteem alone cannot cause language success or vice versa.

\section{Inhibition}

Inhibition is the set of defenses an individual builds to protect himself/herself. The presence of a language ego is considered to be a major hindrance to the process of second language acquisition. The process of making mistakes, learning from those mistakes and a consequent improvement in the language skills get inhibited by this ego. With an adaptive language ego, the learner lowers the inhibitions. An overtly self critical nature perceives the mistakes committed during language learning process as in insult and further slows down the process.

According to Brown (2000) language teaching approaches in the last three decades have been characterized by the creation of contexts in which students are made to feel free to take risks and to orally try out hypotheses. He further claims that it broke down some of the barriers that often make learners reluctant to try out their new language. One 
would clearly agree with him when he argues that If we never ventured to speak a sentence until we were absolutely certain of its total correctness, we would likely never communicate productively at all (Brown, 2000).

\section{Risk-taking}

Risk-Taking is "the ability to make intelligent guesses" (Rubin \& Thompson, 1994). Beebe (1983) described some of the reasons that create fear of risk-taking:

- In the classroom: a bad grade in the course, a fail on the exam, a reproach from the teacher, a smirk from a classmate, punishment or embarrassment imposed by oneself.

- Outside the classroom: fear of looking ridiculous, fear of the frustration coming from a listener's blank look, fear of the alienation of not being able to communicate and thereby get close to other human beings \& fear of losing their identity.

Dufeu (1994) suggests teachers need to establish an adequate affective framework so that learners "feel comfortable" as they take their first public steps in the strange world of a foreign language.

To achieve this teachers have to create a climate of acceptance that will stimulate self-confidence

encourage participants to experiment and to discover the target language

Though risk taking is useful to some extent, high risk-taking will not always yield positive results in second language learning. A number of studies have found that successful language learners make willing and accurate guesses. Thus, it is not always good to be impulsive.

5. Anxiety

Anxiety is a factor that is that is closely related with self-esteem and inhibition and risk-taking. Anxiety can play an important role in L2 learning if it interferes with the learning process. Even though it is a common feeling, it is not easy to define. It comes with the feelings of uneasiness, frustration, self-doubt, apprehension, or worry. A learner's willingness to communicate has also been related to anxiety. It is often affected by the number of people present, the topic of conversation, and the formality of the circumstances.

The two types of anxiety have been identified are:

i. Trait anxiety: it is a more permanent tendency to be anxious

ii. State anxiety: it is a type of anxiety experienced in relation to some particular event or act which can be temporary and context-specific

According to MacIntyre and Gardner, (1991), Trait anxiety, because of its global and somewhat ambiguously defined nature, has not proved to be useful in predicting second language achievement. But, According to Brown (2000), recent research on language anxiety, as it has come to be known, focuses more specifically on the situational nature of state anxiety. Brown (2000) further states that three components of foreign language anxiety have been identified. They are:

i. Communication apprehension, arising from learners' inability to adequately express mature thoughts and ideas;

ii. Fear of negative social evaluation, arising from a learner's need to make a positive social impression on others;

iii. Test anxiety or apprehension over academic evaluation.

Recent research acknowledges that not all anxiety is bad and a certain amount of tension can have a positive effect and facilitate learning. According to its usefulness, two types of anxiety have been identified. They are:

i. Debilitative Anxiety (harmful anxiety)

ii. Facilitative Anxiety (helpful anxiety)

Facilitative anxiety, a positive factor, is the kind of anxiety, concern or apprehension needed to accomplish is. Brown (2000) suggests that it can keep one poised, alert, and just slightly unbalanced to the point that one cannot relax entirely (a symptom of just enough tension to get the job done). Bailey (1983) studied the benefits of facilitative anxiety in learning foreign languages and found that while competitiveness sometimes hindered her progress, at other times it motivated her to study harder. In Bailey's study of competitiveness and anxiety in second language learning, facilitative anxiety was one of the keys to success, closely related to competitiveness.

\section{CONCLUSION}

From the details in the sections given above, one can conclude that individual learner differences play a crucial role in the acquisition of second language. However, despite the efforts of many researchers at reaching a conclusive theory with regard to this, success has eluded them. At present, the scientific study of the role of these differences in second language learning may not be very sophisticated and advanced, but it can be hoped that the growing awareness of the need to focus on the individual student and his individuality in a language learning situation will fuel the need to study the phenomenon in a detailed and empirical manner. Moreover, the analysis of these differences reiterates the commonly held belief that a teacher, especially a language teacher, apart from imparting knowledge must also be a psychologist who can modify his/ her teaching methodology according to the factors related to the individual differences of his/ her students. It is not enough to just know that all students are different from each other. The teacher should also be skilled and willing enough to help the students use these differences to their advantage in the process of second language acquisition. Thus it is hoped that the study of individual differences and their pedagogical implications 
will further lead to the kind of teaching practices that increase the success ratio at second language acquisition.

\section{REFERENCES}

[1] Bacon, S.M., \& M. D. Finneman (1992). Sex differences in self-reported beliefs about foreign language learning and authentic oral and written input. Language Learning 42.4, 471-95.

[2] Bailey, K. M. (1983). Competitiveness and anxiety in adult second language learning: Looking at and through the diary studies. In H. Seliger, \& M. Long (eds.), Classroom oriented research in second language acquisition. Rowley, MA: Newbury House Publishers, 67-102.

[3] Beebe, L. (1983). Risk-taking and the language learner. In H. Seliger \& M. Long (eds.), Classroom oriented research in second language acquisition. Rowley, MA: Newbury House, 39-66.

[4] Boyle, J. (1987). Sex differences in listening vocabulary. Language Learning 37.2, 273- 284.

[5] Brodkey, D., \& H. Shore (1976). Student personality and success in an English language program. Language Learning 26, 153-159.

[6] Brown, H. D. (2000). Principles of language learning and teaching. Englewood Cliffs, N, J.: Prentice-Hall, Inc.

[7] Carroll, J. (1963). The prediction of success in intensive foreign language training. In R. Glazer (ed.), Training research and education. Pittsburgh: University of Pittsburgh Press, 67-102.

[8] Cook, V. (2001). Second language learning and language teaching ( $3^{\text {rd }}$ edn.). New York: Oxford University Press, Inc.

[9] Coopersmith, S. (1967). The antecedents of self-esteem. San Francisco: W. H. Freeman \& Company.

[10] Dewaele, J., \& A. Furnham (1999). Extraversion: The unloved variable in applied linguistic research. Language Learning 49.3, 509-535.

[11] Dufeu, B. (1994). Teaching Myself. London: Oxsford University Press.

[12] Dörnyei, Z. (2005). The psychology of the language learner: Individual differences in second language acquisition. Mahwah, NJ: Lawrence Erlbaum.

[13] Ehrman, M.E. (1996). Understanding Second Language Learning Difficulties. Thousand Oaks, California: SAGE Publications.

[14] Ehrman, M. E., \& R. L. Oxford (1995). Cognition plus: Correlates of language learning success. The Modern Language Journal, 79.1, 67-89.

[15] Gardner, R. C. (1985). Social psychology and second language learning: The role of attitudes and motivation. London: Edward Arnold.

[16] Gardner, R. C., \& W. E. Lambert (1972). Attitudes and motivation in second-language learning. Rowley, MA: Newbury House.

[17] Heyde, A. (1979). The relationship between self-esteem and the oral production of a second language. Ph.D. dissertation, University of Michigan, MI.

[18] Kimura, D. (1992). Sex differences in the brain. Sci Am 267, $119-125$

[19] Kim, H. S., N. R. Relkin, K. M. Lee, \& J. Hirsch (1997). Distinct cortical areas associated with native and second languages. Nature 388, 171-174.

[20] Knowles, M. (1972). Innovations in teaching styles and approaches based upon adult learning. Journal of Education for Social Work 8.2, 32-39.

[21] Krashen, S. (1985). The input hypothesis: Issues and implications. London: Longman.

[22] Larsen-Freeman, D., \& M. H. Long (2000). An introduction to second language acquisition research. London: Longman.

[23] Lochart, C. \& J. C. Richards (1994). Reflective Teaching in Second Language Classrooms. New York: Cambridge University Press.

[24] Lombaard, M. (2006). Task-based assessment for specific purpose Sesotho for personnel in the small business corporation (Doctoral dissertation, Stellenbosch: University of Stellenbosch).

[25] Long, M. (1990). Maturational constraints on language development. Studies in Second Language Acquisition 12, $251-285$.

[26] MacIntyre, P. D., \& R. C. Gardner (1991). Methods and results in the study of foreign language anxiety: A review of the literature. Language Learning 41.1, 283-305.

[27] MacIntyre, P. D., R. Clément, Z. Dörnyei, \& K. A. Noels (1998). Conceptualizing willingness to communicate in a L2: A situational model of L2 confidence and affiliation. The Modern Language Journal 82.4, 545-562.

[28] McDonough, S. H. (1986). Psychology in foreign language teaching. London: George Allen \& Unwin.

[29] O'Malley, J. M., \& A. U. Chamot (1990). Learning strategies in second language acquisition. Cambridge: Cambridge University Press.

[30] Oxford, R.L. (2003). Language learning styles and strategies: An overview. Oxford: GALA

[31] Oxford, R.L. (1993). Instructional implications of gender differences in language learning styles and strategies. Applied Language Learning 4, 65-94.

[32] Oxford R. L., \& M. Ehrman (1992). Second language research on individual differences. Annual Review of Applied Linguistics $13,188-205$.

[33] Oxford, R. L., M. Nyikos \& M. E. Ehrman (1988). Vive la différence? Reflections on sex differences in use of language learning strategies. Foreign Language Annals 21, 321- 329.

[34] Rubin, J., \& I. Thompson, (1994). How to be a more successful language learner, $2^{\text {nd }}$ ed. Boston: Heinle \& Heinle.

[35] Saville-Troike, M. (2006). Introducing second language acquisition. Cambridge: Cambridge University Press.

[36] Skehan, P. (1989). Individual differences in second language learning. London: Edward Arnold.

[37] Slobin, D. I. (1982). Universal and particular in the acquisition of language. In E. Wanner and L. Gleitman (Eds.), Language acquisition: State of the Art (pp. 128-170). Cambridge: Cambridge University Press

[38] Swain, M. (1985). Communicative competence: Some roles of comprehensible input and comprehensible output in its development. In S. M. Gass, \& C. G. Madden (eds.), Input in second language acquisition. Rowley, MA: Newbury House, $235-252$. 
[39] Witkin, H.A. (1973). The role of cognitive style in academic performance and in teacher- student relations. Paper presented at a symposium on Cognitive Styles, Creativity and Higher Education. Sponsored by the Graduate Record Examination Board, Montreal, Canada. Princeton, N.J.: Educational Testing Service, Research Bulletin 73 - 11.

[40] Young, D. J. \& R. L. Oxford (1997). A gender-related analysis of strategies used to process written input in the native language and a foreign language. Applied Language Learning 8, 1-20.

[41] Zhuanglin, H. (1989). Linguistics: An Introduction. Beijing: Peking University Press.

Shahila Zafar is an assistant professor in English at the School of Social Sciences and Languages, VIT University, Vellore, India. Her research interests include second language acquisition, ESL teaching and learning, cultural studies, and black American literature.

K. Meenakshi is an associate professor in English at the School of Social Sciences and Languages, VIT University, Vellore, India. Her research interests include the role of technology in SLA, CALL, and Soft Skills. 